\title{
Short communication: Presence of galactose and glucose promotes browning of sweet whey powder
}

\author{
A. Dattatreya, ${ }^{*}$ W. Lee, $†$ and S. A. Rankin $\ddagger^{1}$ \\ ${ }^{*}$ Mead Johnson Nutrition, Evansville, IN 47221 \\ †Division of Applied and Life Science (Institute of Agricultural \& Life Science), Gyeongsang National University, Jinju 660-701, South Korea \\ ‡Department of Food Science, University of Wisconsin-Madison, 1605 Linden Drive, Madison 53706
}

\section{ABSTRACT}

This research examined the role of sugar type on the browning of sweet whey powder during accelerated storage. Two model systems, a lactose-lysine system and a sweet whey powder system, were selected. Within each model system experiment were samples containing equimolar concentrations of lactose, galactose, and glucose, and model systems were studied at $3 \mathrm{pH}$ values: $6.5,6.0$, and 5.5. Samples were analyzed for changes in color after accelerated browning at $80^{\circ} \mathrm{C}$ for $24 \mathrm{~h}$. The results showed that the samples containing galactose and glucose browned to a greater degree than those containing lactose. Browning in the control and lactoseenriched samples was more susceptible to changes in $\mathrm{pH}$. This study indicates that the processing conditions of liquid whey in which the lactose monomers glucose and galactose accumulate may predispose SWP to brown more readily.

Key words: residual sugar, Maillard browning, sweet whey powder

Sweet whey powder (SWP), which is generally white, may brown during storage due to nonenzymatic Maillard type reactions (Doob et al., 1942; Labuza and Saltmarch, 1981). Several factors affect the browning potential of SWP. During thermal processing and storage, reactions eventually leading to Maillard browning occur involving amine and carbonyl moieties such as those found on amino acids and reducing sugars, respectively (Ellis, 1959). Reactive compounds in SWP, specifically lysine and lactose, readily participate in the Maillard reaction in the presence of moisture, resulting in brown pigmentation (Labuza and Saltmarch, 1981). Nonenzymatic browning through the Maillard reaction is considered a major deteriorative mechanism active during the storage of SWP (Burin et al., 2000). Compositionally, SWP is rich in lysine-containing pro-

Received November 23, 2009.

Accepted February 4, 2010.

${ }^{1}$ Corresponding author: sarankin@wisc.edu teins and the reactive reducing sugar lactose $(\sim 70 \%)$. Depending on the processing and storage conditions of liquid whey, additional reducing sugars, the lactose monomers galactose and glucose, may be produced as lactose is metabolized (Rao et al., 2004). Certain lactic acid bacterial cultures, such as Streptococcus salivarius ssp. thermophilus, are known to preferentially ferment the glucose portion of the lactose molecule, allowing galactose to accumulate in the whey (Rao et al., 2004). Rao et al. (2004) found that the galactose content increased from 0.14 to $0.63 \mathrm{~g} / \mathrm{L}$ in Cheddar cheese whey and from 0.71 to $1.87 \mathrm{~g} / \mathrm{L}$ in Mozzarella cheese whey after abusive storage conditions $\left(24 \mathrm{~h}\right.$ at $\left.37.8^{\circ} \mathrm{C}\right)$. Galactose content in whey derived from cheese made with single-strain starter cultures during storage $(24 \mathrm{~h}$, $37.8^{\circ} \mathrm{C}$ ) varied from 0.24 to $3.06 \mathrm{~g} / \mathrm{L}$. The initial rate of reducing sugar-dependent browning with a given amino compound is related to the extent and rate at which the sugar's cyclic hemiacetal structure exists in the open, reducible form (Overend et al., 1961). Sugars with the highest concentration of acyclic form at equilibrium have been shown to brown at correspondingly increased rates (Burton and McWeeney, 1963). Among the hexoses, D-galactose, D-mannose, and D-glucose show decreased ring opening and decreased browning rates in the order given (Burton and McWeeney, 1963). Burton and McWeeney (1963) also proposed that the initial aldose-amine reaction and the rate of production of chromophore compounds depend on the conformational stability of the aldose molecule. The amounts of acyclic forms of sugars and mutarotation rates correspond well with the relative rates of browning with the pentoses being highest, followed by hexoses, then disaccharides (Labuza and Schmidl, 1986). For example, lactose is known to have a browning extent (expressed as the extinction coefficient at $550 \mathrm{~nm}, \mathrm{E}_{550}$ ) of 0.003 , whereas glucose and galactose have values of 0.011 and 0.030 , respectively, when reacted with glycine (Hashiba, 1982). Most studies on browning mechanisms are conducted in aqueous model systems. It is not known if the same phenomena occur in dry systems, especially one as complex as SWP. We hypothesized that the residual 


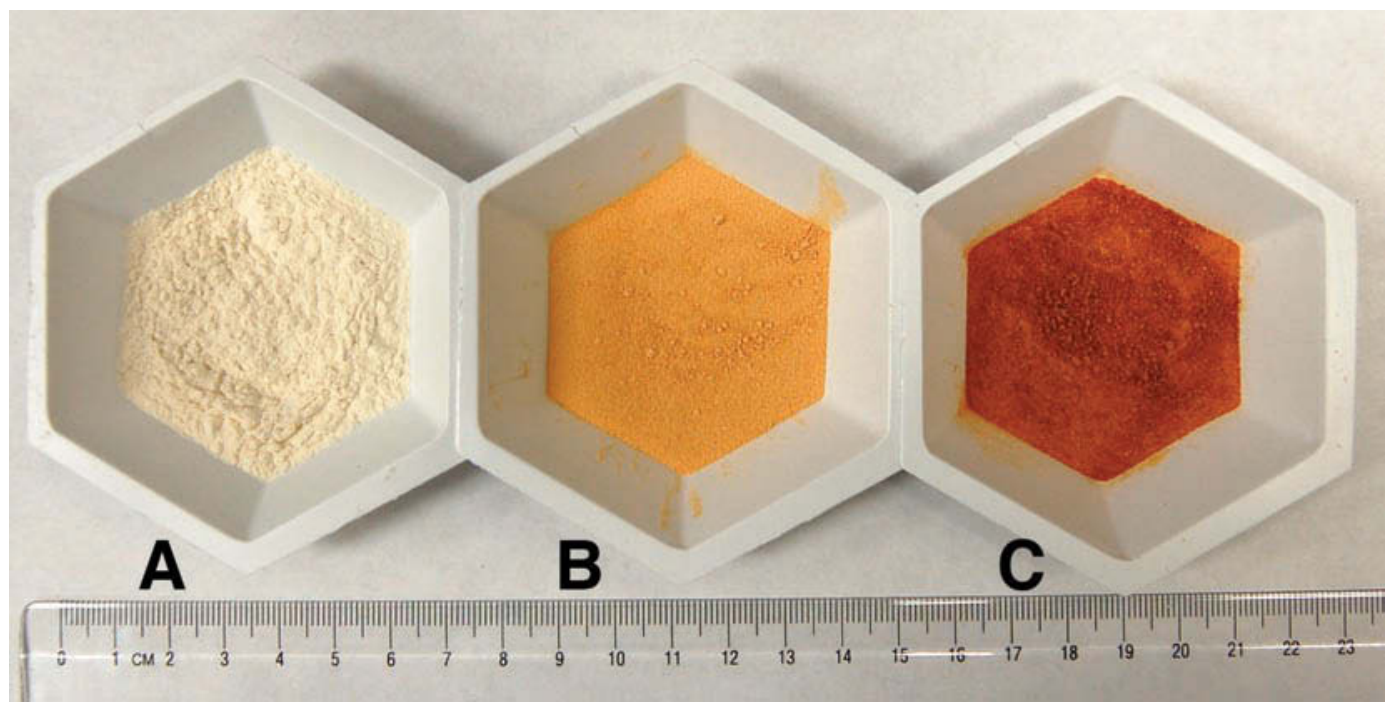

Figure 1. Images of selected sweet whey powder samples at various stages of browning for visual reference. Samples B and C were subjected to browning at $80^{\circ} \mathrm{C}$ for $24 \mathrm{~h}$. Average $\mathrm{L}^{*}$ values are $90.8,80.8$, and $59.2 ; \mathrm{a}^{*}$ values are $-0.32,+6.13$, and +14.5 ; and $\mathrm{b}^{*}$ values are $+4.78,+31.1$, and +36.7 for samples $\mathrm{A}, \mathrm{B}$ and $\mathrm{C}$, respectively. Color version available in the online PDF.

lactose monomers galactose and glucose can accumulate in liquid whey and will predispose SWP to brown more readily. The objective of the present study was to analyze the role of these residual sugars on the browning of SWP under conditions of accelerated storage.

The study was conducted using 2 model systems, a lactose-lysine system and a SWP system. In the lactoselysine system, $2 \mathrm{~L}$ of $5.2 \%$ lactose solution containing $0.093 \%$ lysine was prepared (corresponding to $0.1443 \mathrm{M}$ lactose and $0.0064 M$ lysine; the ratio simulating their respective concentrations in liquid whey) and divided into 4 samples of $500 \mathrm{~mL}$ each. One treatment was unaltered and served as the control, whereas the other treatments contained a known quantity of lactose (3.0 $\mathrm{g} / \mathrm{L})$, galactose $(1.5 \mathrm{~g} / \mathrm{L})$, or glucose $(1.5 \mathrm{~g} / \mathrm{L})$ yielding $0.017 M$ equimolar concentrations. Similarly, a more authentic system was prepared wherein SWP (Foremost Farms, Baraboo, WI) was reconstituted (6.5\% in distilled water) and divided into 4 samples of 500 $\mathrm{mL}$ each. One treatment was unaltered and served as control. To the other treatments, equimolar concentrations $(0.017 M)$ of lactose, galactose, or glucose were added and solubilized. The experiment was replicated over 3 different $\mathrm{pH}$ values: $6.5,6.0$, and 5.5 , obtained by adding $\mathrm{NaOH}$ or $\mathrm{HCl}(1 N)$. The $\mathrm{pH}$ of reconstituted powders $(2 \mathrm{~g}$ of powder $+10 \mathrm{~mL}$ of distilled water) was measured using a pH meter (Accumet model 15, Fisher Scientific, Pittsburgh, PA).

All of the samples were freeze-dried to an average moisture of $3.5 \%( \pm 0.2)$ and water activity of 0.23 $( \pm 0.1)$. A $10-\mathrm{g}$ sample of each treatment was placed into a $40-\mathrm{mL}$ glass vial with Teflon-lined cap and subjected to accelerated browning at $80^{\circ} \mathrm{C}$ for $24 \mathrm{~h}$ (Anupama and Rankin, 2006). The color of samples was determined using the CIE Lab method to measure the parameters $\mathrm{L}^{*}$ (lightness), $\mathrm{a}^{*}$ (redness), and $\mathrm{b}^{*}$ (yellowness) using illuminant D65 at $10^{\circ}$ observer angle (Colorquest, 45/0, Hunterlab, Reston, VA). Analysis of variance was conducted using a 2-way complete block design, and pairwise comparisons were conducted when the treatment effects $(\mathrm{pH}$, sugar type, and $\mathrm{pH} \times$ sugar type interaction) were significant at the $\alpha<0.05$ level (JMP v. 7.0.1., SAS Institute Inc., Cary, NC).

As points of reference for SWP, L* values decrease (become darker), $\mathrm{a}^{*}$ values increase (become redder), and $b^{*}$ values decrease (become bluer) over the course of browning. Panels A, B, and C in Figure 1 show representative visual samples of SWP with varying degrees of browning with corresponding $\mathrm{L}^{*}, \mathrm{a}^{*}$, and $\mathrm{b}^{*}$ values.

In the sugar-lysine system, $\mathrm{pH}$, sugar type, and the $\mathrm{pH} \times$ sugar type interaction term each had a significant effect on $\mathrm{L}^{*}$ values (Table 1 ). In general, $\mathrm{L}^{*}$ values were lower as $\mathrm{pH}$ decreased with the exception of the galactose treatments, in which the reverse was true. The $\mathrm{L}^{*}$ values in both the glucose and galactose treatments were substantially lower than those in the control and lactose treatments, suggesting a higher reactivity rate or the creation of a more intensely colored brown pigment. The galactose-treated samples were darker (lowest $\mathrm{L}^{*}$ value) than the other treatments. Similar effects were noted with the SWP system (Table 2) in that the $\mathrm{L}^{*}$ values decreased with $\mathrm{pH}$. The average effect of sugar type on browning was less pronounced, but with a trend similar to that observed for the sugar-lysine 
Table 1. Mean $\mathrm{L}^{*}, \mathrm{a}^{*}$, and $\mathrm{b}^{*}$ color values of samples of sugar-lysine model system samples after accelerated browning at $80^{\circ} \mathrm{C}$ for $24 \mathrm{~h}$

\begin{tabular}{|c|c|c|c|c|c|c|c|c|c|c|c|c|}
\hline \multirow[b]{2}{*}{ Sugar type } & \multicolumn{4}{|c|}{$L^{*}$} & \multicolumn{4}{|c|}{$a^{*}$} & \multicolumn{4}{|c|}{$b^{*}$} \\
\hline & $\mathrm{pH} 6.5$ & $\mathrm{pH} 6.0$ & $\mathrm{pH} 5.5$ & Average & $\mathrm{pH} 6.5$ & $\mathrm{pH} 6.0$ & $\mathrm{pH} 5.5$ & Average & $\mathrm{pH} 6.5$ & $\mathrm{pH} 6.0$ & $\mathrm{pH} 5.5$ & Average \\
\hline Control & $67.8^{\mathrm{a}}$ & $61.9^{\mathrm{a}}$ & $59.9^{\mathrm{a}}$ & $63.2^{\mathrm{a}}$ & $5.38^{\mathrm{a}}$ & $6.74^{\mathrm{b}}$ & $7.03^{\mathrm{ab}}$ & $6.38^{\mathrm{b}}$ & $20.1^{\mathrm{a}}$ & 21.3 & $23.9^{\mathrm{b}}$ & $21.8^{\mathrm{b}}$ \\
\hline Lactose & $69.4^{\mathrm{a}}$ & $64.9^{\mathrm{a}}$ & $61.9^{\mathrm{a}}$ & $65.4^{\mathrm{a}}$ & $5.05^{\mathrm{a}}$ & $5.81^{\mathrm{a}}$ & $6.50^{\mathrm{a}}$ & $5.79^{\mathrm{a}}$ & $19.4^{\mathrm{a}}$ & 20.4 & $22.2^{\mathrm{ab}}$ & $20.7^{\mathrm{a}}$ \\
\hline Galactose & $46.8^{\mathrm{c}}$ & $50.9^{\mathrm{b}}$ & $53.7^{\mathrm{b}}$ & $50.5^{\mathrm{c}}$ & $8.37^{\mathrm{c}}$ & $6.99^{\mathrm{b}}$ & $7.34^{\mathrm{b}}$ & $7.57^{\mathrm{c}}$ & $23.7^{\mathrm{b}}$ & 20.1 & $21.6^{\mathrm{a}}$ & $21.8^{\mathrm{b}}$ \\
\hline Glucose & $54.4^{\mathrm{b}}$ & $53.2^{\mathrm{b}}$ & $53.1^{\mathrm{b}}$ & $53.5^{\mathrm{b}}$ & $6.50^{\mathrm{b}}$ & $6.51^{\mathrm{b}}$ & $6.72^{\mathrm{a}}$ & $6.57^{\mathrm{b}}$ & $21.3^{\mathrm{a}}$ & 19.8 & $21.5^{\mathrm{a}}$ & $20.9^{\mathrm{a}}$ \\
\hline Average & $59.6^{\mathrm{A}}$ & $57.6^{\mathrm{B}}$ & $57.2^{\mathrm{B}}$ & & $6.32^{\mathrm{A}}$ & $6.51^{\mathrm{AB}}$ & $6.90^{\mathrm{B}}$ & & $21.1^{\mathrm{B}}$ & $20.4^{\mathrm{A}}$ & $22.3^{\mathrm{C}}$ & \\
\hline
\end{tabular}

${ }^{\mathrm{a}-\mathrm{c}}$ Means within a column followed by different lowercase letters are significantly different $(P<0.05)$.

${ }^{\mathrm{A}-\mathrm{C}}$ Means within this row followed by different uppercase letters are significantly different $(P<0.05)$.

Table 2. Mean $\mathrm{L}^{*}, \mathrm{a}^{*}$, and $\mathrm{b}^{*}$ color values of samples of sweet whey powder model system samples after accelerated browning at $80^{\circ} \mathrm{C}$ for $24 \mathrm{~h}$

\begin{tabular}{|c|c|c|c|c|c|c|c|c|c|c|c|c|}
\hline \multirow[b]{2}{*}{ Sugar type } & \multicolumn{4}{|c|}{$\mathrm{L}^{*}$} & \multicolumn{4}{|c|}{$a^{*}$} & \multicolumn{4}{|c|}{$b^{*}$} \\
\hline & $\mathrm{pH} 6.5$ & $\mathrm{pH} 6.0$ & $\mathrm{pH} 5.5$ & Average & $\mathrm{pH} 6.5$ & $\mathrm{pH} 6.0$ & $\mathrm{pH} 5.5$ & Average & $\mathrm{pH} 6.5$ & $\mathrm{pH} 6.0$ & $\mathrm{pH} 5.5$ & Average \\
\hline Control & $43.7^{\mathrm{a}}$ & $40.5^{\mathrm{a}}$ & $34.2^{\mathrm{a}}$ & $39.5^{\mathrm{b}}$ & $13.8^{\mathrm{a}}$ & $13.7^{\mathrm{a}}$ & $13.9^{\mathrm{a}}$ & $13.8^{\mathrm{a}}$ & $31.6^{\mathrm{b}}$ & $29.7^{\mathrm{b}}$ & $26.2^{\mathrm{a}}$ & $29.1^{\mathrm{b}}$ \\
\hline Lactose & $43.1^{\mathrm{a}}$ & $41.3^{\mathrm{a}}$ & $35.4^{\mathrm{b}}$ & $40.0^{\mathrm{b}}$ & $13.6^{\mathrm{a}}$ & $13.4^{\mathrm{a}}$ & $13.7^{\mathrm{a}}$ & $13.6^{\mathrm{a}}$ & $31.3^{\mathrm{b}}$ & $30.0^{\mathrm{b}}$ & $27.4^{\mathrm{b}}$ & $29.6^{\mathrm{c}}$ \\
\hline Galactose & $38.1^{\mathrm{b}}$ & $34.3^{\mathrm{b}}$ & $34.2^{\mathrm{a}}$ & $35.5^{\mathrm{a}}$ & $14.2^{\mathrm{b}}$ & $14.4^{\mathrm{b}}$ & $14.3^{\mathrm{b}}$ & $14.3^{\mathrm{b}}$ & $29.6^{\mathrm{a}}$ & $27.4^{\mathrm{a}}$ & $26.3^{\mathrm{a}}$ & $27.8^{\mathrm{a}}$ \\
\hline Glucose & $37.3^{\mathrm{b}}$ & $33.2^{\mathrm{b}}$ & $36.3^{\mathrm{c}}$ & $35.6^{\mathrm{a}}$ & $14.2^{\mathrm{b}}$ & $14.4^{\mathrm{b}}$ & $14.1^{\mathrm{b}}$ & $14.2^{\mathrm{b}}$ & $29.1^{\mathrm{a}}$ & $26.7^{\mathrm{a}}$ & $27.3^{\mathrm{b}}$ & $27.7^{\mathrm{a}}$ \\
\hline Average & $40.5^{\mathrm{C}}$ & $37.3^{\mathrm{B}}$ & $35.0^{\mathrm{A}}$ & & 13.9 & 14.0 & 14.1 & & $30.4^{\mathrm{C}}$ & $28.5^{\mathrm{B}}$ & $26.8^{\mathrm{A}}$ & \\
\hline
\end{tabular}

${ }^{a-c}$ Means within a column followed by different lowercase letters are significantly different $(P<0.05)$.

${ }^{\mathrm{A}-\mathrm{C}}$ Means within this row followed by different uppercase letters are significantly different $(P<0.05)$. 
system with the monomer treatments darkening to a greater degree than the lactose and control samples. In both the sugar-lysine system and the SWP system, the lactose and control treatments were affected to a greater degree than the monomer treatments as $\mathrm{pH}$ decreased, leading to a significant $\mathrm{pH} \times$ sugar type interaction effect.

The $\mathrm{a}^{*}$ values were also significantly affected by $\mathrm{pH}$, sugar type, and $\mathrm{pH} \times$ sugar type interaction in the sugar-lysine system. In general, the average $a^{*}$ values increased with a decrease in $\mathrm{pH}$ with the exception of the galactose-treated samples (hence, a significant $\mathrm{pH}$ $\times$ sugar type interaction effect). The effect of sugar type on $\mathrm{a}^{*}$ values was significantly greatest for the galactose-treated samples. For the SWP samples, although a minor increase in average values was noted as the $\mathrm{pH}$ decreased, the overall effect of $\mathrm{pH}$ treatment on $\mathrm{a}^{*}$ values was not significant at the $\alpha<0.05$ level. The effect of sugar type on $a^{*}$ values in the SWP was highest for the galactose treatment and lowest for the control and lactose treatments; however, this effect was different across $\mathrm{pH}$ values.

The $b^{*}$ values for the sugar-lysine system were significantly affected by $\mathrm{pH}$ and sugar type and there was a strong effect of the $\mathrm{pH} \times$ sugar type interaction. In general, the $\mathrm{b}^{*}$ values were lowest for the $\mathrm{pH} 6.0$ treatment for the galactose- and glucose-treated samples. The control and lactose treatments showed an increase in $\mathrm{b}^{*}$ values as the $\mathrm{pH}$ decreased, but the glucose and galactose samples had $\mathrm{b}^{*}$ minima at $\mathrm{pH}$ 6.0. The effect of sugar type on $\mathrm{b}^{*}$ was also influenced by $\mathrm{pH}$ in that the glucose and galactose treatments had the highest $\mathrm{b}^{*}$ values at $\mathrm{pH}$ 6.5, whereas the lactose and control samples had the highest values at $\mathrm{pH} 6.0$ and 5.5. The SWP samples were more strongly influenced by the main treatments of sugar type and $\mathrm{pH}$ than the lactose-lysine system samples. In general, the $b^{*}$ values decreased as the $\mathrm{pH}$ decreased, and the glucose and galactose treatments yielded lower $b^{*}$ values than the lactose and control samples.

This study demonstrates that residual sugars have a significant influence on the relative browning extent of SWP during accelerated storage. The presence of sugars, especially the hexoses galactose and glucose, can accelerate the browning reaction. These monosaccharides are thought to increase the initial rate of reducing sugar-dependent browning with a given amino compound mainly by increasing the rate at which the sugar's ring opens to a reactive, reducible form (Overend et al., 1961). In contrast to many browning phenomena in which acidic conditions impede browning, this study demonstrated that browning increased as $\mathrm{pH}$ decreased for the control and lactose-enriched samples in both systems. The potentiation of browning under dry, mildly acidic conditions was demonstrated in earlier work (Anupama and Rankin, 2006) in which the pathway involving the 3-deoxyosone intermediate was proposed. The $\mathrm{pH}$ effect was not manifest in the samples containing added galactose or glucose potentially because of the extensive browning that occurred in these systems.

\section{REFERENCES}

Anupama, D., and S. A. Rankin. 2006. Moderately acidic $\mathrm{pH}$ potentiates browning of sweet whey powder. Int. Dairy J. 16:822-828.

Burin, L., K. Jouppilla, Y. Roos, J. Kansikas, and M. D. P. Buera. 2000. Color formation in dehydrated modified whey powder systems as affected by compression and $\mathrm{T}_{\mathrm{g}}$. J. Agric. Food Chem. 48:5263-5268.

Burton, H. S., and D. J. McWeeney. 1963. Nonenzymatic browning reactions: Consideration of sugar stability. Nature 197:266-268.

Doob, H., A. Willmann, and P. F. Sharp. 1942. Influence of moisture on browning. Ind. Eng. Chem. 34:1460-1468.

Ellis, G. P. 1959. The Maillard reaction. Adv. Carbohydr. Chem. 14:63-134.

Hashiba, H. 1982. The browning reaction of Amadori compounds derived from various sugars. Agric. Biol. Chem. 46:547-548.

Labuza, T., and M. Saltmarch. 1981. Kinetics of browning and protein quality loss in whey powders during steady state and non-steady state storage conditions. J. Food Sci. 47:92-96.

Labuza, T. P., and M. K. Schmidl. 1986. Advances in the control of browning reactions in foods. Pages 65-95 in Role of Chemistry in the Quality of Processed Food. O. R. Fennema, W.-H. Chang and C.-Y. Lii, ed. Food and Nutrition Press Inc., Westport, CT.

Overend, W. G., A. R. Peacocke, and J. B. Smith. 1961. Reactions at position 1 of carbohydrates. Part I. The polarographic reduction of carbohydrates. J. Chem. Soc. 3487-3497.

Rao, R. D., W. L. Wendorff, and K. Smith. 2004. Changes in galactose and lactic acid content of sweet whey during storage. J. Food Prot. 67:403-406. 